\title{
KOEBNER PHENOMENON CAUSED BY BLOODLETTING AND CUPPING THERAPY IN A PATIENT WITH PSORIASIS
}

\author{
Stoyan Pavlov ${ }^{1,2}$, Milka Dimitrova $^{2}$ \\ ${ }^{1}$ Department of Infectious Diseases, Parasitology and Dermatovenereology, \\ Faculty of Medicine, Medical University of Varna \\ ${ }^{2}$ Department of Dermatology and Venereal Diseases, \\ St. Marina University Hospital, Varna
}

\begin{abstract}
The Koebner phenomenon refers to the appearance of isomorphic lesions on areas of cutaneous injury in otherwise healthy skin areas. This is a common skin reaction presented by the German dermatologist Heinrich Koebner (1838-1904) in 1872. In addition to the name Koebner phenomenon, it is also called the isomorphic response. We report a case of a 26-year-old man with a 10-year history of psoriasis vulgaris. The patient had been treated with bloodletting and cupping therapy for chronic back pain and developed psoriatic papules and plaques in the places of injuries. The presented case confirms the role of iatrogenic trauma as a trigger for the formation of psoriatic plaques in patients with clinically manifested disease.
\end{abstract}

Keywords: Koebner phenomenon, psoriasis vulgaris, cupping, bloodletting

\section{INTRODUCTION}

The Koebner phenomenon refers to the appearance of isomorphic lesions on the areas of cutaneous injury in otherwise healthy skin. It is described by the German dermatologist Heinrich Koebner (1838-1904) in 1872 at the Meeting of the Silesian Society of National Culture and in 1877 he published a paper reporting the appearance of psoriatic lesions after traumatic injury, such as bruises, tattoos, and horse bites (1). It is called the Koebner phenomenon or the isomorphic response. The

Address for correspondence:

Stoyan Pavlov

Faculty of Medicine

Medical University of Varna

55 Marin Drinov St

9002 Varna

e-mail: stoyanpavlov@abv.bg

Received: September 3, 2019

Accepted: September 15, 2019
Koebner phenomenon occurs in many dermatoses, but the three main related diseases are psoriasis, vitiligo, and lichen planus. In psoriasis, the incidence of Koebner phenomenon varies widely according to the different studies from $27 \%$ to $75 \%$ (2). In vitiligo, the phenomenon frequency ranges from $5 \%$ to $61 \%$ (3). In lichen planus, the incidence is up to $28 \%$ (1). The term Koebner phenomenon is not used in the cases where the event is secondary to infectious or allergenic agents. Boyd and Neldner classified all the isomorphic and isotopic responses (Table. 1) (4).

The pathogenesis of the Koebner phenomenon is still obscure, but several theories have been developed.

1. Immunological: Immune factors, including immune complexes, chemotactic molecules and lymphocytes are involved.

2. Vascular: The histopathological characteristics associated with psoriasis involve capillary dilatation in the papillary dermis. These vessels become permeable and can later respond to traumatic stimuli. 
Table.1. Isomorphic and isotopic responses (Boyd and Neldner 1990)

\begin{tabular}{|c|c|c|c|c|c|}
\hline $\begin{array}{l}\text { Classical } \\
\text { Isomorphic } \\
\text { Response }\end{array}$ & $\begin{array}{l}\text { Occasional } \\
\text { Koebner } \\
\text { Phenomenon }\end{array}$ & Pseudo-Köebner & $\begin{array}{l}\text { Reverse Koebner } \\
\text { Phenomenon }\end{array}$ & $\begin{array}{l}\text { Wolf Isotopic } \\
\text { Phenomenon }\end{array}$ & $\begin{array}{c}\text { Rënbok } \\
\text { Phenomenon }\end{array}$ \\
\hline $\begin{array}{l}\text { Lichen planus } \\
\text { Psoriasis } \\
\text { Vitiligo }\end{array}$ & $\begin{array}{l}\text { Darier's disease } \\
\text { Pellagra } \\
\text { Leukocytoclastic } \\
\text { vasculitis } \\
\text { Allergic purpura } \\
\text { Bullous pemphi- } \\
\text { goid } \\
\text { Dermatitis her- } \\
\text { petiformis } \\
\text { Erythema multi- } \\
\text { forme } \\
\text { Lupus erythema- } \\
\text { tosus } \\
\text { Lichen sclerosus } \\
\text { Lichen nitidus } \\
\text { Hailey-Hailey } \\
\text { disease } \\
\text { Sarcoidosis } \\
\text { Kyrle's disease } \\
\text { Pityriasis rubra } \\
\text { pilaris } \\
\text { Eruptive xan- } \\
\text { thoma } \\
\text { Morphea } \\
\text { Perforating fol- } \\
\text { liculitis } \\
\text { Granuloma an- } \\
\text { nulare }\end{array}$ & $\begin{array}{c}\text { Verrucae } \\
\text { Impetigo } \\
\text { Molluscum } \\
\text { contagiosum } \\
\text { Kaposi's Sarcoma }\end{array}$ & $\begin{array}{l}\text { Psoriasis } \\
\text { Vitiligo } \\
\text { Granuloma } \\
\text { annulare }\end{array}$ & $\begin{array}{c}\text { Primary } \\
\text { dermatoses } \\
\text { Striae } \\
\text { Herpes simplex } \\
\text { Herpes zoster } \\
\text { Secondary } \\
\text { dermatoses } \\
\text { Acne } \\
\text { Psoriasis } \\
\text { Bowen's disease } \\
\text { Granuloma } \\
\text { annulare } \\
\text { Metastatic } \\
\text { carcinoma } \\
\text { Connective } \\
\text { tissue disease } \\
\text { Lymphoma } \\
\text { Lichen planus }\end{array}$ & $\begin{array}{c}\text { Primary } \\
\text { dermatoses } \\
\text { Alopecia areata } \\
\text { Alopecia } \\
\text { universalis } \\
\text { Secondary } \\
\text { dermatoses } \\
\text { Psoriasis } \\
\text { Congenital nevus } \\
\text { Pathergy } \\
\text { Pyoderma } \\
\text { gangrenosum } \\
\text { Behçet's disease } \\
\text { Sweet's syndrome }\end{array}$ \\
\hline
\end{tabular}

3. Dermal: Researchers have suggested that the degree of reactivity depends on the depth of the trauma: the dermis and the epidermis should be involved.

4. Growth factors: Researchers have found that psoriatic plaques induced by experimental trauma occur by keratinocyte proliferation and overregulation of the nerve growth factor (NGF) in basal keratinocytes.

5. Neural: Involving Schwann cells, perineural cells, and axons.

6. Genetic: X-linked genetic mutation could be related.

7. Hormonal.

8. Infections: Antigens cross-reactions with streptococci in the epidermis.
9. Drugs: Certain drugs, such as $\beta$-blockers, lithium, synthetic antimalarial drugs, nonsteroidal anti-inflammatory agents, and tetracyclines may aggravate psoriasis and induce koebnerization (1).

\section{CASE REPORT}

We report a case of a 26-year-old man with a 3-month history of small erythematous elevated plaques with a diameter of 5-15 $\mathrm{mm}$, located paravertebral to his back (Fig. 1). The lesions are rounded and linearly ordered, presented of silvery white squamous plaques (Fig. 2, Fig .3). Apart from these changes, the patient had numerous erythematous plaques with a diameter of $2-10 \mathrm{~cm}$ on his upper and lower extremities (Fig. 4). These erythematous lesions had been diagnosed as psoriasis vulgaris 10 years before. 
One month before the appearance of the new exanthema, the patient reported for self-performed bloodletting cupping procedure for chronic back pain. The presented changes reflected and appeared at the regions of placement of the cupping glasses, followed by incisions and pinches to achieve bloodletting. The long-term history of low back pain is considered a clinical manifestation of probable psoriatic arthritis as sacroileitis. The routinely studied laboratory tests (CBC, CRP, liver enzyme tests) did not show abnormalities. The skin biopsy revealed dilated dermal papillae and angioproliferation, acanthoses, diminished granular cell layer and parakeratosis (Fig. 5). Based on the clinical and histological findings we confirmed psoriasis vulgaris. The newly emerged lesions have been determined to be a result of Koebner phenomenon caused by bloodletting and cupping therapy. Corticosteroids and emollients were administered for topical treatment of the new psoriatic rashes located symmetrically on the back of the patient (Fig. 1, Fig. 3). The therapeutic regimen consisted of methylprednisolone aceponate cream, once daily for 10 days, followed by twice daily administration of bethamethazone valerate, which was diluted in emollient with a ratio of $1: 10$, for the next 10 days. The erythema and infiltrate decreased significantly, and the plaque desquamation disappeared.

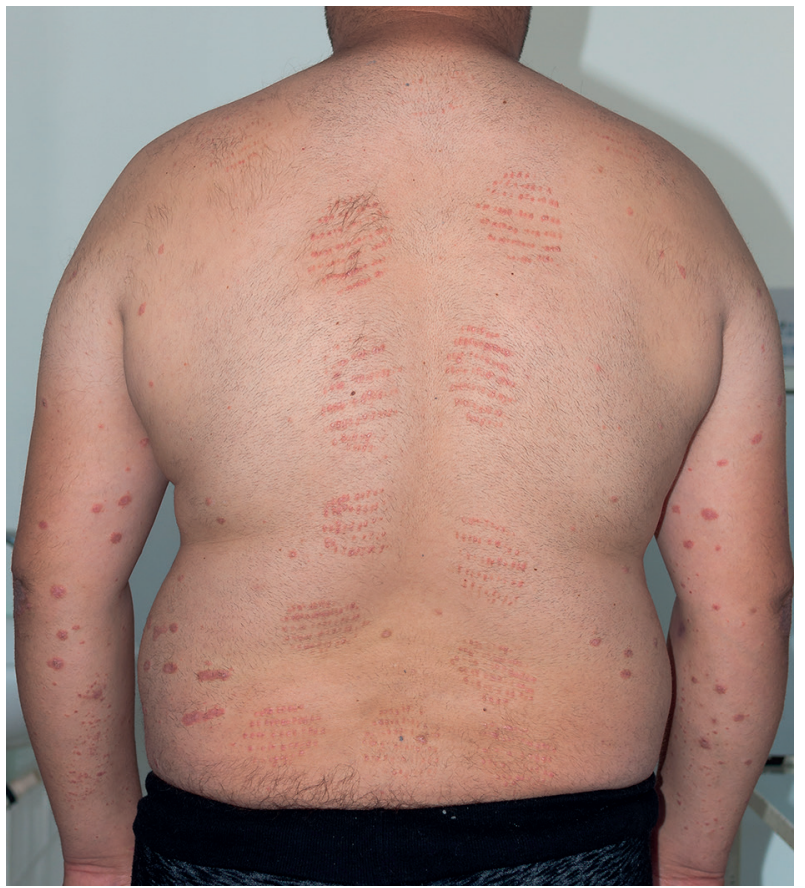

Fig. 1. Psoriatic plaques located in the paravertebral area

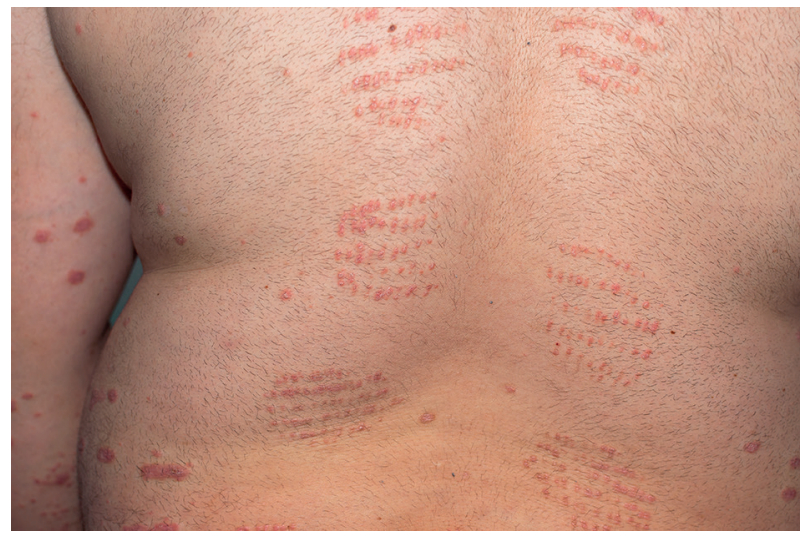

Fig. 2. Papules located in the places of previous scarification

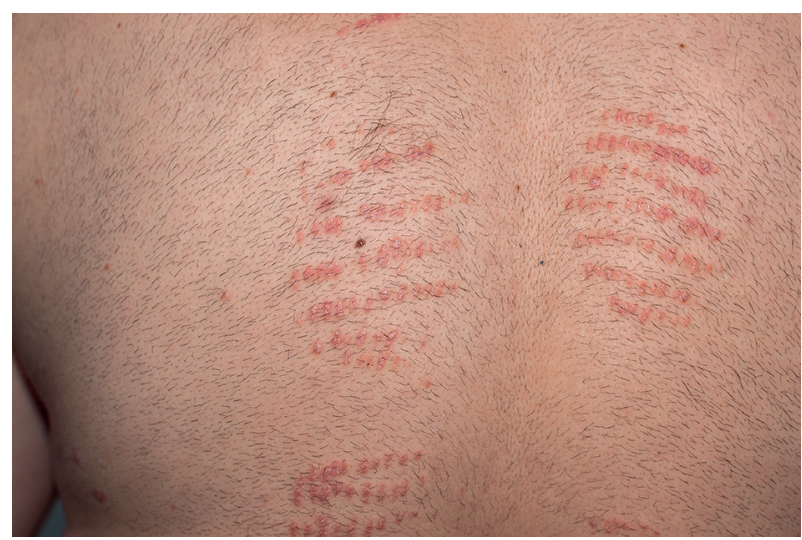

Fig. 3. Linearly arranged psoriatic papules

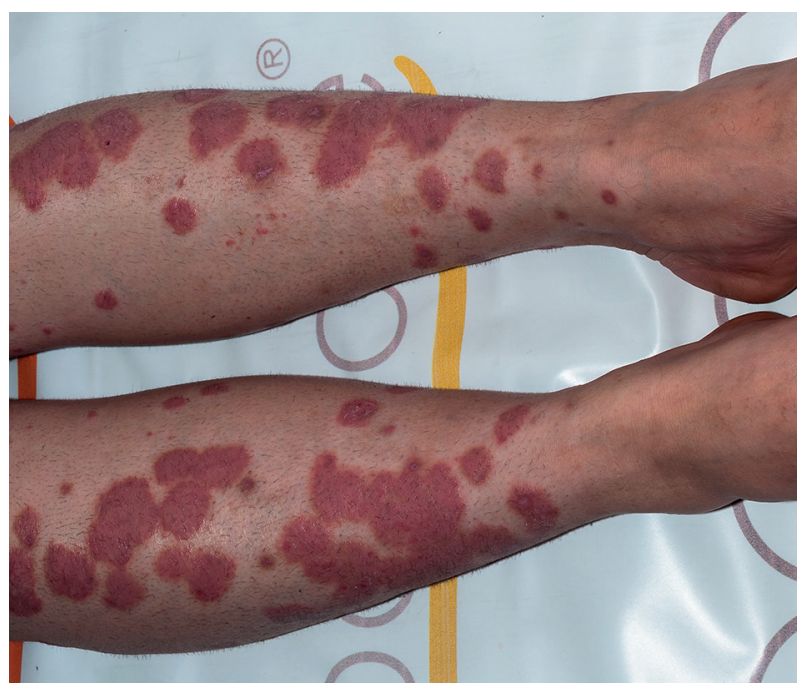

Fig. 4. Erythematous plaques 


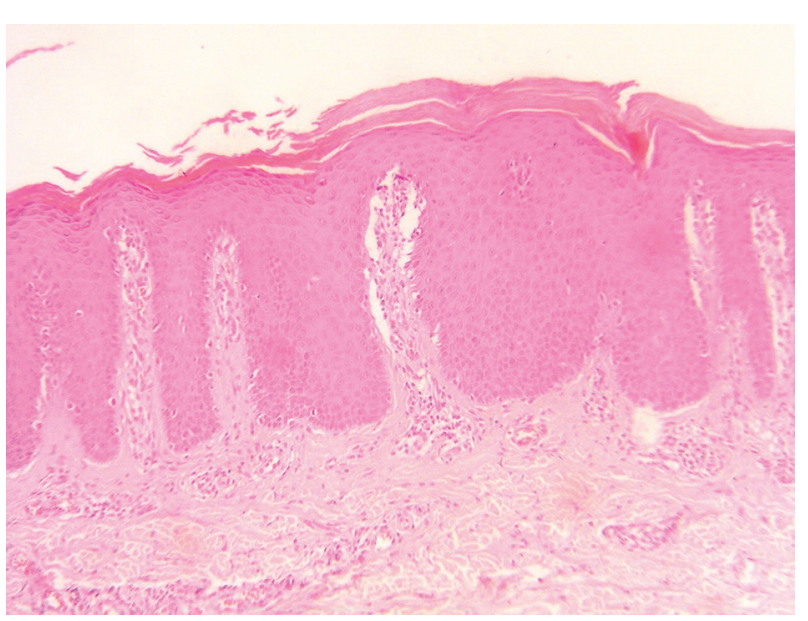

Fig. 5. Dilated dermal papillae and angioproliferation, acanthoses, diminished granular cell layer, and parakeratosis. HE $\times 40$

\section{DISCUSSION}

Cupping therapy consists of manually fixed cupping glass for zone marking. Afterwards, the suction caps are removed, a number of linearly aligned needle or scalpel pinches are placed in the marked spots and suction caps are placed again in the same spots. In China, the earliest records of cupping can be found in Bo Shu, a book written on silk, discovered in an ancient tomb of the Han Dynasty and since then it has become an integral part of traditional Chinese medicine. It is used in the following conditions: blood circulations, detoxification, immune system strengthening, hormonal disorders, fibromyalgia, neck and head pain, migraine and sinusitis, chronic fatigue, hypertension, acne, psoriasis, hair loss, depression, sleep disorders, digestive problems, growth and development in children, and hyperactivity (5). Well-known in traditional Chinese medicine, cupping therapy is accepted and practiced by some other ancient cultures as a traditional therapeutic method for treating a number of diseases. In India, Ayurvedic medicine is widely accepted with historical roots and traditions. The purification of various "toxins" from the body and a series of „purification procedures" known as "panchakarma", one after the other, are performed. Cupping therapy is part of the so-called "blood purification“ (rakta moksha) and is one of the methods of body purification in Ayurvedic medicine (6). This practice has become widespread and popular in ancient Egypt (7). The murals and papyruses found in the tomb of Tutankhamun and in the temple of Kom-Ombo testify to it. Cupping therapy was transferred from Egypt to ancient Greece, subsequently. The technique of cupping therapy combined with bloodletting, as well as in its dry variant, is described by the Hippocrates and he recommends using both. The Romans adopted cupping therapy, refining it with the use of blood-sucking leeches $(8,9)$.

Nowadays, cupping therapy is widely used in clinical practice to reduce back and waist pain in patients with locomotor system problems (10). It is combined with laser acupuncture in some cases (11). Despite the abundance of historical data, current scientific literature lacks high quality medical studies on the curative effect of cupping therapy. There are no large randomized placebo-controlled, as well as double-blind studies, which makes the published results controversial and debatable (12). The putative mechanism of action of cupping therapy in patients with non-specific chronic low back pain is not fully understood yet. More clinical studies with tailored therapeutic modalities are needed to clarify the mechanisms and efficacy of cupping therapy (10).

\section{CONCLUSION}

The presented clinical case demonstrates a Koebner phenomenon induced by the combined impact of vacuum and superficial incisions for bloodletting at the area of cupping glass position. Our patient suffered from unusual location of the psoriatic exanthema as a consequence of the traumatic skin injury.

\section{REFERENCES}

1. Camargo CM dos S, Brotas AM, Ramos-eSilva M, Carneiro S. Isomorphic phenomenon of Koebner: facts and controversies. Clin Dermatol. 2013;31(6):741-9. doi: 10.1016/j. clindermatol.2013.05.012.

2. Braun-Falco O, Burg G, Farber EM. [Psoriasis. A questionnaire study of 536 patients]. Munch Med Wochenschr. 1972;114(23):1105-10.

3. Handa S, Kaur I. Vitiligo: clinical findings in 1436 patients. J Dermatol. 1999;26(10):653-7. doi: 10.1111/j.1346-8138.1999.tb02067.x.

4. Boyd AS, Neldner KH. The isomorphic response of Koebner. Int J Dermatol. 1990;29(6):401-10. doi: 10.1111/j.1365-4362.1990.tb03821.x. 
5. El-Wakil A. Observations of the popularity and religious significance of blood-cupping as an Islamic medicine. Contemp Islam Stud. 2011;2011(2011):2.

6. Thappa D, Gupta D. Dermatoses due to Indian cultural practices. Indian J Dermatol. 2015;60(1):3. doi: 10.4103/0019-5154.147778.

7. Mehta P, Dhapte V. Cupping therapy: A prudent remedy for a plethora of medical ailments. J Tradit Complement Med. 2015;5(3):127-34. doi: 10.1016/j. jtcme.2014.11.036.

8. Whitaker I., Rao J, Izadi D, Butler P. Historical Article: Hirudo medicinalis: ancient origins of, and trends in the use of medicinal leeches throughout history. Br J Oral Maxillofac Surg. 2004;42(2):1337. doi: 10.1016/S0266-4356(03)00242-0.

9. Sig AK, Guney M, Uskudar Guclu A, Ozmen E. Medicinal leech therapy-an overall perspective. Integr Med Res. 2017;6(4):337-43. doi: 10.1016/j. imr.2017.08.001.
10. Silva HJDA, Saragiotto BT, Silva RS, Lins CADA, De Souza MC. Dry cupping in the treatment of individuals with non-specific chronic low back pain: A protocol for a placebo-controlled, randomised, double-blind study. BMJ Open. 2019;9(12): e032416. doi: 10.1136/bmjopen-2019-032416.

11. Lin ML, Wu JH, Lin CW, Su CT, Wu HC, Shih YS, et al. Clinical effects of laser acupuncture plus chinese cupping on the pain and plasma cortisol levels in patients with chronic nonspecific lower back pain: a randomized controlled trial. Evidencebased Complement Altern Med. 2017;2017:3140403. doi: 10.1155/2017/3140403.

12. Qureshi NA, Ali GI, Abushanab TS, El-Olemy AT, Alqaed MS, El-Subai IS, et al. History of cupping (Hijama): a narrative review of literature. J Integr Med. 2017;15(3):172-81. doi: 10.1016/ S2095-4964(17)60339-X. 